\title{
Lumen
}

Selected Proceedings from the Canadian Society for Eighteenth-Century Studies

Travaux choisis de la Société canadienne d'étude du dix-huitième siècle

\section{Gotthold Ephraim Lessing's Samuel Henzi: the non-fragmentary status of the text}

\section{Christa Fell}

Volume 19, 2000

Material Productions \& Cultural Construction

Culture matérielle \& Constructions discursives

URI : https://id.erudit.org/iderudit/1012317ar

DOI : https://doi.org/10.7202/1012317ar

Aller au sommaire du numéro

Éditeur(s)

Canadian Society for Eighteenth-Century Studies / Société canadienne d'étude du dix-huitième siècle

ISSN

1209-3696 (imprimé)

1927-8284 (numérique)

Découvrir la revue

Citer cet article

Fell, C. (2000). Gotthold Ephraim Lessing's Samuel Henzi: the non-fragmentary status of the text. Lumen, 19, 89-97. https://doi.org/10.7202/1012317ar

Copyright (c) Canadian Society for Eighteenth-Century Studies / Sociéte canadienne d'étude du dix-huitième siècle, 2000
Ce document est protégé par la loi sur le droit d'auteur. L'utilisation des services d'Érudit (y compris la reproduction) est assujettie à sa politique d'utilisation que vous pouvez consulter en ligne.

https://apropos.erudit.org/fr/usagers/politique-dutilisation/ 


\section{Gotthold Ephraim Lessing's Samuel Henzi: the non-fragmentary status of the text.}

In this time of postmodern thinking where everything is said to be fated to remain a fragment, it is not inappropriate to pay attention to an alleged literary fragment of the past and to see what validity - even wholeness - it might have. Recovering one of Lessing's literary efforts is the subject of this study.

Although authored by Lessing, Samuel Henzi is not a household name in German literature. However, Götz von Berlichingen, Egmont, Wilhelm Tell and Samuel Henzi have a common denominator; these heroes of dramatic writings all fought for an idea - for rights and freedom from an abusive political system. The title, Samuel Henzi, signifies, as do most of Lessing's eponymous titles, not only the protagonist of the play but also its geographical location. Thus, Samuel Henzi points to Switzerland. It is somewhat ironic to unearth an event in Swiss history which opposes the image we retain of that country as a freedom- and peace-loving nation.

The historical circumstances surrounding Samuel Henzi typify the times. In the course of the Eighteenth Century violent disturbances of a revolutionary nature swept through Western Europe, including Switzerland. Such actions were mostly concentrated in small areas and kept in check by the authorities before they gave way to the explosion of the French Revolution. It was the year 1749, forty years before the French Revolution. For Lessing, who was just twenty, it was an extremely productive, yet turbulent year - an unsettled time in his life. Like other young men of his age, he was unsure of his calling: would it be theology, medicine, acting, or some kind of writing? In that year he wrote: Tarantula and Weiber sind Weiber, both of which remained fragments; Der Freigeist, exposing the religious fanaticism of his time; Die Juden; and Samuel Henzi, which was conceived in the wake of the Henzi revolt in 
Bern. It should not be ignored that he also translated Crébillon's Catilina and Rollin's Historie Romaine depuis la Fondation de Rome from French, both of which expounded ideas on republicanism.

In his life-long search and struggle for truth, Lessing primarily explored contemporary issues through the media of journalism and the stage. For him, the theatre functioned as a forum in which he was able to exhibit his opinions on crucial matters in the public sphere. He was not only a Sucher (a searcher for truth) but also a Versucher in both senses of the word. ${ }^{1}$ In his literary works he tried to depart from the classical French canon with appropriate pieces which could serve as models for a future German drama; in that way he introduced the genre of domestic tragedy to the German stage. This notion of cultural independence and autonomy is linked to the emergence of German nationalism - one of Lessing's special concerns (Stahr 67ff).

His intent of expanding traditional genres for his own needs led him to create texts which would strike a chord in the German audience. The Saxon comedy with which he was familiar not only gave him that opportunity but also legitimized his intentions. The works of 1749 , with the exception of Samuel Henzi, are labelled 'comedies,' although the term as applied to Die Juden becomes moot given the way Lessing manipulates the genre. ${ }^{2}$ In this one-act comedy, which is recognized as a complete work and runs parallel in time to the so-called Henzi 'fragment,' his innovating process can be demonstrated.

We are confronted in Die Juden with a criminal case, a detective story with a twist, in which the audience is aware of the culprit from the outset. The title is misleading. It sets up false expectations both because of its plural form since only one Jew appears on stage and because of the assumption, according to the standards of the Saxon comedy which Lessing tried to emulate, that Jews would be objects of ridicule. This is by no means the case. It is a marvellous play of reverse psychology based on unfounded prejudice in society. ${ }^{3}$ The ending of the play is rather unconventional, too. Out of gratitude for having saved his life, the baron promises his daughter to the unidentified 'foreigner.' But the expected marriage, the usual happy ending of the comedy, does not materialize because the foreigner reveals his identity: he is a Jew. Furthermore, in the same way as later in Minna von Barnhelm, in Die Juden the defining lines between comedy and tragedy begin to blur, as much as do the traditional requirements for class distinctions in the plays. The shock effect on contemporaries would have resembled that of Brecht's Verfremdungseffekt. This sort of provocation is more than an authorial fad. The audience together with the baron were to look into a mirror in order to change their misconceived attitudes and possibly the rigid laws against the Jews in Prussia as well. 
Lessing's works seem to intertwine at this point. It is not so much the invention of a totally new genre, but a genre in flux with which he engenders a transformation of social behaviour by providing 'new' or different models of identification, and which I would like to term 'experimental genre.' Stahr points out Lessing's penchant for independence as a ground for achieving individual development, thus creating new functions for literary forms (120). Such manipulation of traditional literary genres could express an implicit negation of the norms of bourgeois society or at least provide the author with a critical standpoint for which he had to invent a specific textual form. The author's interpretation of the historical events is reflected in Samuel Henzi, published in his Schrifften of 1753, a collection of critical literary pieces in the fashionable letter-form. Two of these letters incorporate the text of Samuel Henzi. Lessing did not label it a fragment. It is identified at this point as a tragedy (Muncker 5:97). But it does not fit all the established characteristics of this genre. It is the treatment of an obviously contemporary issue not distanced in time at all. Lessing even dared to use in his play the real names of the participants in the Henzi revolt. Not only did he appropriate those names, he even distorted the character image of a man who was alive and behind bars. This was considered outrageous by Albrecht von Haller for example (Stenzel 1206ff), and also in conflict with Lessing's own concept of historical truth as later spelled out in his Hamburgische Dramaturgie, Stück 19 and 23-25 (Muncker 9:260ff; 277-89).

While this study questions the fragmentary nature of the text, a brief summary of the background material and the historical events which led up to the writing of Samuel Henzi is necessary to understand this dramatic piece. Lessing confesses that no other event had moved him more in recent years than the decapitation of Mr. Henzi in Bern (Muncker 5:97). The newspaper articles on the case which appeared in the Berlinische Privilegierte Zeitung, and to which Lessing had access, were quite numerous. They cover the period from July 9 to October 17. Although Henzi had been executed on July 17th, 1749, political tensions were in existence beyond that time. Flyers with a graphic text were even distributed on October 12th, 'worinne man wegen des vergossenen Bürgerbluts Rache fordert' (Stenzel 1197). Together with oral accounts, they formed the background material for the dramatic text. ${ }^{4}$ But these contemporary material details do not figure in the text itself, except that Lessing was bold enough to use the names of the participants in the conspiracy.

How did the fatal situation emerge? In the previous fifty years nepotism, corruption and oppression prevailed in the once free city state of Bern which had turned into an oligarchy ruled by only four families who succeeded in slowly abolishing the established democratic institutions. Two attempts had been made in the past to rectify this dismal situation: 
the first was in 1710 and the second in 1744, with the result that whoever had signed the circulated petition was silenced by exile. Among them was Samuel Henzi, who was allowed back into the country in 1748, only to get involved in the planning of another conspiracy out of patriotism. This one was stirred up by a man named Dücret who intended to usurp the government. However, the plans were betrayed, and Henzi with two others, Fuetter and Wernier, was executed. Dücret was sentenced to life in prison because he was not a subject of the Bern republic. The fact that he came from a noble family in Geneva spoke for itself. He also had wisely transformed his name from du Crest into Dücret in order to camouflage his aristocratic descent.

If we examine the more or less preconscious impulses that might have motivated Lessing's fascination with the case we discover that he must have felt personal affinities with Samuel Henzi. ${ }^{5}$ Like Henzi he was the son of a pastor, came from the same social milieu without financial resources, and worked his way up into a position as a journalist and writer. Both wrote with enthusiasm and imagination and were stark enemies of Gottsched. As Lutheran Protestants both writers must have felt the right to resist an unjust and oppressive state authority.

No wonder that Lessing was deeply moved by Henzi's fate and felt a desire to portray this experience in a dramatic plot so as to preserve the moment. In catering to these sentiments, the drama brings forth - more implicitly than explicitly - certain features of what Lessing imagined the recent history 'to be.' The historical moment is captured in the condensed period of one day in Samuel Henzi, other events of the past being represented only as a backdrop. Lessing does this with the greatest possible immediacy: he concentrates on an imaginative description of a moment in time before the discovery of the plot by the magistracy, making present a historical ethos which he imagined existing among the conspirators. It offers insight into the dynamics of conspiracy - the interactions of individuals in which the perils of political and personal associations become evident; it penetrates the participants' psyches. Devoid of circumstances which would explain the actual happenings of the conspiracy and provide us with a literary and historical frame, Lessing wishes to thematize a state of confusion propelled by distrust among the dramatic characters.

His intentions are stated in a letter: contrasting the rebel with the patriot, Dücret with Henzi (Muncker 5:111), ${ }^{6}$ he portrays a situation in which the political ideologies of revolution and reform clash, the participants in the plot being torn between them, uncertain whom they should believe, whom they can trust, in short whom they should support and follow. In the clash of these two political frameworks the intellectual dissonances and contradictions are captured. The dialogues function to 
frame, complicate and mirror the dynamics of trust and mistrust. The real world of human encounter where justice and the good become questionable is reflected here. An atmosphere of distrust is created from the very beginning when Henzi comes on stage. The questions posed in a hectic sequence show Henzi in a state of disarray: 'Wer folgt mir? Liebster Freund? bist dus? - Wen suchst du? - Mich? Du folgst mir nach? - Warum?' (Stenzel 498). He feels persecuted and appears to suffer from a lack of self-confidence. Without trust and confidence he has almost lost his political goal from the onset. He is not motivated by egotistic desire for power and control. The driving force behind his actions is a quest for truth. Although he is a person of moral and human commitment, sufficiently patient and disciplined, he is profoundly suspicious of the senses and any understanding that might grow from them. He only wants to re-establish the rights which grant the burgher freedom and a polity in which a sense of order and dignity reign and in which people are not moved by greed to seek power. He rejects violent acts, tolerating them only in exteme situations.

Lessing presents Dücret as Henzi's antagonist, unethical to his last fibre. Infatuated with power, he is a man of action without responsibility; he acts hastily without pondering the consequences for others or himself. 'Dieser Genfische Rebell,' as he is called in a letter of July 9, 1749 by a member of the magistracy (Stenzel 1180), ${ }^{7}$ refuses to prolong the agony of waiting, whereas Henzi is the ponderer. Dücret is referred to as a 'Wüterich' (Stenzel 511-12), a tyrant - a key concept in the text. With demagogic power, he is unscrupulous and contemptuous of all forms of inquiry. He is a fanatic, who tries to seduce and manipulate the group. $\mathrm{He}$ is without conscience, shame or guilt, driven only by hatred and bloodthirstiness - characteristics of the anarchist. Both parties are advocates for rights and freedom, but their methods differ greatly. It becomes obvious that the group of conspirators is not a cohesive unit. They are confused - divided between Henzi and Dücret - nor do they know whom to trust.

In this brief text, allusiveness has an important function, since it supplies the reader with understanding of the issues addressed. As emphasized by Barner, models of republicanism in Rome are always recalled in the themes of patriotic love (217), which was regarded as a typical republican virtue and linked to the emergence of national consciousness. Thus, it is not surprising that Marcus Brutus is mentioned (Stenzel 501) since he murdered Caesar to save the republic. But this act of violence did not solve the problem; the struggle went on. We are confronted with Cicero's 14 Philippicae Orationes (Stenzel 503) which were directed against Marcus Antonius who, after Caesar's death, intended to take power in Rome. Upon his order, Cicero was banished and 
murdered. From a historical viewpoint, the right to resist and the value of resisting a despot becomes questionable, particularly when reference is made to 'jener Held' (Stenzel 500) - the famous Athenian leader Phokion. He was forced to drink the poison-cup in 398 BC because he opposed corruption. The term 'Rottengeist' (Stenzel 504) is noteworthy in this context; it denotes the bitter taste of crime and blasphemy, being extensively used by Luther to signify rebels. ${ }^{8}$ The schematized past presents affinities directed to a specific thematic field.

These historical incidents offer an interesting picture. Overthrowing the government and committing murder in a supposedly good cause solves nothing because one anarchy simply replaces another. Can violence ever be permitted and to what degree? Is slow improvement of the desperate political situation possible if you are not in power (Stenzel 514)? These questions are justified partly because questions are raised throughout the text; it even starts with a series of questions. But where are the answers? Judging from the disunity of the conspirators and the confusion heightened by the historical allusions, it is a foregone conclusion that the plot is doomed to fail.

The play consists of two acts with three scenes each. One-act plays, especially comedies, were fashionable at the time, and Lessing resorted to them. He wrote a one-act tragedy Philotas in 1759 . So, why could two acts not be considered an autonomous text? Lessing deviates from the norm in other instances when he had certain intentions in mind. In the case of Henzi he writes a two-act tragedy dealing with contemporary events. The argument that he did not finish the drama to protect himself, since he had addressed a sensitive, controversial issue, does not hold much water. After all, he did publish the text. To my knowledge, none of his more clearly identifiable fragments were published during his lifetime - a fact not to be ignored. ${ }^{9}$ It is only in the ensuing secondary literature that Samuel Henzi is referred to as a fragment.

The text was originally embedded in Letters 22 and 23 of Lessing's Schrifften - in the volume containing the early comedies. Although Lessing denies the fictional character of these letters (Muncker 5:37), the fact that he himself published them means that they left the private realm and entered the public domain; the actual recipient, identified only by initials, remained camouflaged. Moreover, it can be argued that their literary subject matter was meant for a wider readership than a single correspondent. The emphasis on the non-fictionality of the letters is probably one of Lessing's favourite, provocative rhetorical devices. ${ }^{10}$

It has been argued that Lessing gave up the project because he could not cope with the Alexandrian verse form. This supposition should be refuted on the grounds that no indication in the text itself substantiates this claim. After all, he used this form in the translations of Catilina and 
Marivaux's Hannibal. It is, however, the only element, besides the three traditional unities of time, place and action, linking the text to the established genre of tragedy. Lessing is aware that he is a beginner on the literary scene and must adhere to the rules of tragedy (Muncker $5: 110)$. He dares not take a major risk with his audience and justifies not having masked the actual events or the names of the rebels. Thus, he does not flinch from the truth (Muncker 5:110-11).

By incorporating the Henzi text into two letters and pretending not to have finished the work from mere inability, Lessing urges his addressee to complete the play (Muncker 5:112); this person is identical with the reader of the letters. In this context a further textual feature should not be ignored. The last word in the text is 'etc' (Stenzel 517), an unusual ending for an alleged fragment; it does not appear in Lessing's indisputably fragmentary writings. It can be argued that he had a purpose in using this locution: the goal of suggesting further lines of thought. This goal would not consist with the text being thought a fragment. To attach meaning to this 'etc,' two possibilities come to mind:

(1) what follows in one's imagination is the events as recorded in newspaper reports. Since Lessing wrote for his contemporaries, he did not have to reiterate known facts; they would have been familiar with the Henzi case. In addition, through intertextual referentiality even the non-contemporary reader knows only too well how it all will end and that the political problem will not be solved by violence. It will go on and on - 'etc.' We could add the insight that such literature is politicized at the level of its explicit articulation. Lessing applies here the same technique he uses later on in Nathan's Ringparabel. After we hear that the father has died and left each of his three sons with a ring, a tense moment is created. Nathan pauses and the Sultan urges him to finish his 'fairytale.' Nathan answers: 'Ich bin zu Ende. Denn was noch folgt, versteht sich ja von selbst' (Muncker 3:209). The 'etc' could function in the same way: on the basis of known facts the outcome can be predicted.

(2) There is no single dominant form for imagining or re-presenting history. The seeming incompleteness of the story - not the play - can be read as a symbolic gesture. The conspiracy in Bern did not come to an end, and, uncompleted like the original mission, the drama remains in a state of apparent unfinishedness, reflecting the political situation in Bern which did not change after the bloodshed. The 'etc' would then refer to a continuum expressing Lessing's scepticism and matching the poignant examples from Greek and Roman history. Forty years before the French Revolution, a massive political change was still unthinkable. 
Unfortunately, no one imitated or developed the discourse Lessing invented. The choice of his subject in Henzi, his fragmentary tragedy Spartacus (circa 1770) and his plan for Masaniello (1773), connected as they are by political allusiveness, form a web of realities which attests to the thought that history as a unilinear development no longer exists, even if we accept a certain sequentiality as a frame of reference. If the non-fragmentary status of Lessing's play remains in doubt, Samuel Henzi is a worthwhile experiment. If its completeness is acknowledged, it should be considered Lessing's first Bürgerliches Trauerspiel.

\section{CHRISTA FELL \\ Queen's University}

\section{Notes}

1 Versuchen in German means to try, to attempt, or to seduce, to entice.

2 They were not published until 1754 and not performed until 1766.

3 Hildebrandt formulates it concisely when he praises Lessing for using the theatre as a 'Turnierplatz gegen Vorurteile' (119).

4 They might have come from Christlob Mylius who corresponded with the mathematician Samuel König who, like Henzi, was exiled from Bern in 1744 (Stenzel 1200).

5 See also Loeb. In 1748, ironically, Henzi authored a Telldrama, Grisler ou l'Helvétie délivrée, which parallels the Samuel Henzi drama in expressing patriotic sentiments.

6 Patriot, in the eighteenth-century context, denotes a person whose concern is the general welfare of the citizens and the public well-being of the state as defined by the immediate territory - the fatherland.

$7 \mathrm{He}$ is the prototype of a rebel, in contrast to Henzi who refuses to be in charge of a group of rebels. According to Zedler, a rebel is someone who disturbs the public peace and agitates others, too: 'Rebelle,Rebell: Stör=Fried, Tumultant, unruhiger Kopff, Auffwiegler, Auffrührer, Meutmacher, Meutenirer, Friedbrecher, ein von seinem Ober=Herrn abgefallener oder untreu gewordener' (30:1233). The meaning of rebel in the Eighteenth Century is well expressed by Henzi:

Ist denn der Blutdurst auch zu einer Tugend worden?

Und ist es Bürgerpflicht die Bürger zu ermorden?

Ein Vorsatz gleicher Art steht nur Rebellen an.

(Stenzel 514).

8 Martin Luther, Wider die räuberischen und mörderischen Rotten der Bauern, 1525.

9 Lessing had left quite a few fragments in his Nachla 3 , some of which were published posthumously by his brother Karl. As an independent text, not embedded in two Letters, Samuel Henzi was published in Gotthold Ephraim Lessings Theatralischer Nachla 3 II, 1784, under the title Samuel Henzi, ein Trauerspiel, 
Berlin, 1749. From then on, it was marginalized to the status of a fragment. See also Barner 83.

10 E.g. Lessing's later public confession in the Hamburgische Dramaturgie: 'Ich bin weder Schauspieler noch Dichter' (Muncker 10:92).

\section{Works Cited}

Albrecht, Wolfgang. Gotthold Ephraim Lessing. Stuttgart;Weimar: Metzler, 1997.

Barner, Wilfried et al. Lessing, Epoche-Werk-Wirkung. München: Beck, $1976^{2}$.

Grimm, Jacob und Wilhelm. Deutsches Wörterbuch. vol 30. Reprint München: dtv, 1984.

Hildebrandt, Dieter. Lessing: Biographie einer Emanzipation. München;Wien: Hanser, 1979.

Gotthold Ephraim Lessing 1743-1750. ed. Jürgen Stenzel. vol 1. Frankfurt/M: Deutscher Klassiker Verlag, 1989.

Gotthold Ephraim Lessings sämtliche Schriften. eds. Karl Lachmann, Franz Muncker. 23 vols. Stuttgart: Göschen et al.,1890ff.

Loeb, Ernst. 'Lessings Samuel Henzi. Eine aktuelle Thematik.' Monatshefte 65 (1973): 351360.

Stahr, Adolf. Gotthold Ephraim Lessing. Sein Leben und seine Werke. 2 vols. Berlin: Gutten$\operatorname{tag}, 1877^{8}$.

Zedler, Johann Heinrich. Großes Vollständiges Universal-Lexikon. Leipzig; Halle: verlegts Johann Heinrich Zedler, 1741. Fotographic reprint: Graz: Akademische Druck- und Verlagsanstalt, 1961-64. 